\title{
Association of rs610604 in TNFAIP3 and rs17728338 in TNIP1 gene polymorphisms with psoriasis susceptibility: A meta-analysis of case-control studies
}

\author{
Hai-bo Gong \\ People's Hospital of Xinjiang Uygur Autonomous Region https://orcid.org/0000-0002-9094-3031 \\ Shu-tao Gao \\ The First Affiliated Hospital of Xinjiang Medical University \\ Xiong-ming Pu ( $\sim$ Puxiongming@126.com ) \\ https://orcid.org/0000-0003-2837-3223 \\ Xiao-jing Kang \\ People's Hospital of Xinjiang Uygur Autonomous Region \\ Xiu-juan Wu \\ Shanghai Xuhui Central Hospital
}

Research article

Keywords: Psoriasis, TNFAIP3, TNIP1 Single nucleotide polymorphism, Meta-analysis

Posted Date: October 23rd, 2019

DOI: https://doi.org/10.21203/rs.2.16320/v1

License: (c) (i) This work is licensed under a Creative Commons Attribution 4.0 International License. Read Full License

Version of Record: A version of this preprint was published at BMC Medical Genetics on May 12th, 2020. See the published version at https://doi.org/10.1186/s12881-020-01041-x. 


\section{Abstract}

Background: To date, The pathological mechanisms underlying the occurrence and development of psoriasis are still unanswered questions. Genome-wide association surveys have revealed that TNFAIP3 and TNIP1 were key biomarkers for psoriasis. This study aimed to investigate the association between TNFAIP3 and TNIP1 gene polymorphisms with psoriasis susceptibility.

Methods Comprehensive literature search was undertook across four online databases-PubMed, Embase, Cochrane Library, and China National Knowledge Infrastructure (CNKI) up to August 25, 2019. Allele model of inheritance was used to analyze the original data. Newcastle-Ottawa scale (NOS) was used to evaluate the risk bias of each study. Pooled odds ratios and $95 \%$ confidence intervals were calculated using the RevMan 5.3 software.

Results In all, 13 case-control studies comprising 13,908 psoriasis patients and 20,051 controls were identified and included in this meta-analysis. The results demonstrated that rs610604 in TNFAIP3 polymorphism was significantly associated with psoriasis risk using random effect model ( $\mathrm{G}$ vs. T, OR $=1.19,95 \% \mathrm{Cl}: 1.09-1.31, \mathrm{P}=0.0002$ ), and a significant association between rs17728338 in TNIP1 polymorphism and psoriasis vulnerability using fixed effect model (A vs. G, OR $=1.69,95 \% \mathrm{Cl}: 1.58-1.80, \mathrm{P}<0.00001$ )

Conclusions This meta-analysis indicated that rs610604 in TNFAIP3 and rs17728338 in TNIP1 gene polymorphisms were associated with psoriasis susceptibility.

\section{Introduction}

Psoriasis is currently regarded as a chronic, inflammatory skin disease associated with systemic conditions ${ }^{1-3}$. As with other dermatoses, the patients who suffered from it also have to face the huge psychological burden because of visible disfiguration. Considerable comorbid disease occur more often in psoriasis patients, including psoriatic arthritis, metabolic syndrome, cardiovascular disorders, gastrointestinal diseases, mood disorders as well as other emerging comorbid diseases ${ }^{4}$. Psoriasis affects approximately $2 \%-3 \%$ of the population world-wide, and its prevalence is much higher in western countries ${ }^{5,6}$. To data, five types of psoriasis have been identified: psoriasis vulgaris, guttate, flexural psoriasis, pustular psoriasis, pustular psoriasis ${ }^{3}$.

As a complex inflammatory disorder, the etiology and pathogenesis of psoriasis is widely thought to be caused by the interplay of intrinsic and environmental factors. Numerous triggers for psoriasis occurrence and aggravation have been identified, such as Mild localized trauma, drugs, HIV infection, Streptococcal pharyngitis and exposure to natural sun light $^{7}$. However, intrinsic factors such as genetics may play a more important role. Thanks to the powerful genome-wide association studies (GWAS) as well as other genetic studies, more than 60 regions of the human genome have now been identified to be correlate with psoriasis ${ }^{8}$. Tumor Necrosis Factor Alpha-Induced Protein 3 (TNFAIP3) and TNFAIP3 Interacting Protein 1 (TNIP1) are among them, they were first discovered to be associated with psoriasis in $2009^{9}$.

TNFAIP3 gene is located on human chromosome 6q23.3, while TNIP1 is located on 5q33.1. They are all Protein Coding gene encoding ubiquitin-editing enzyme A20 and A20-Binding Inhibitor Of NF-Kappa-B Activation 1 (ABIN-1), which interact with each other to influence intracellular signaling ${ }^{10,11}$. The interrelation network of TNFAIP3 and TNIP1 with their nearest associated functional protein partners were illustrated on Fig. 1. Over the years, accumulating evidence indicated that genetic variations in the genes TNFAIP3 and TNIP1 are strongly associated with vulnerability to numerous inflammatory diseases ${ }^{12-14}$. Considering that study sample sizes were small and the statistical effect was limited of an individual study, this meta-analysis is meant to provide the most comprehensive and precise evaluation on the association of TNFAIP3 and TNIP1 polymorphisms with psoriasis vulnerability. 


\section{Materials And Methods \\ Search strategy}

Two of our investigators (Hai-bo Gong and Shu-tao Gao) independently searched four major databases-PubMed, Embase, Cochrane library, CNKI-for papers published before August 25, 2019. The search strategy for PubMed was as follows: ((((Psoriasis) OR “Psoriasis”[Mesh])) AND ((((((“Tumor Necrosis Factor alpha-Induced Protein 3”[Mesh]) OR Tumor Necrosis Factor alpha-Induced Protein 3) OR Zinc Finger Protein A20) OR A20) OR TNF Alpha-Induced Protein 3)) OR ((((((“TNIP1 protein, human” [Supplementary Concept]) OR TNIP1) OR TNFAIP3 Interacting Protein 1) OR A20-Binding Inhibitor Of NF-Kappa-B Activation 1) OR VAN protein, human) OR TNFalpha-induced protein 3-interacting protein 1, human) OR ABIN-1 protein, human))) AND ((((((single nucleotide polymorphism) OR Polymorphism) OR Alleles) OR SNP) OR Variation) OR gene).

\section{Inclusion and exclusion criteria}

The PICOS (population, intervention, comparison, outcome, and study design) principle was used to generate the inclusion criteria for the present study, which were as follows: case control studies on humans; published studies on the association of TNFAIP3 or TNIP1 polymorphisms with BD susceptibility; and available data to calculate the odds ratios (ORs) and 95 $\%$ confidence intervals (95\% Cls). In contrast, Studies met the following criteria should be excluded: reviews, non-human studies, lack of sufficient data to evaluate ORs and Cls, and duplicated articles.

\section{Data extraction}

Hai-bo Gong and Shu-tao Gao independently evaluated and extracted all necessary data from each candidate article including: first author, year of publication, Ethnicity of study population, numbers of cases and controls, and the allele frequencies of the TNFAIP3 or TNAP1 polymorphisms, Hardy-weinberg equilibrium (HWE) results.

\section{Quality assessment}

Newcastle-Ottawa Scale (NOS) was used to assess all included studies in accordance with its criteria. "Score system" was applied to judge every included study on three broad aspects: Selection of case and control groups ( $0-4$ points); Comparability of case and control groups ( $0-2$ points); and Ascertainment of exposure for included studies ( $0-3$ points). Studies with $\geq 5$ scores were considered as a high quality. If there were discrepancy in this process, the two authors would discuss and arrive at consensus with the third author (Xiong-ming Pu).

\section{Statistical analysis}

The preferred Reporting Items for systematic Review and Meta-analyses (PRISMA) was used to complete this metaanalysis $^{15}$. We perform this Meta-analyses using allele model of inheritance owing to the lack of sufficient information. The association between rs610604 in TNFAIP3 and rs17728338 in TNIP1 polymorphisms with psoriasis was calculated by merging ORs with $95 \%$ Cls. Q-statistical test and $\mathrm{I}^{2}$ test were used to evaluate the heterogeneity among all included studies $^{16}$. The random effect model was used to combine the data in the cases of heterogeneity $\left(P<0.1, I^{2}>50 \%\right)$ or fixed-effect model was used when it was out of heterogeneity $\left(P>0.1, \mathrm{I}^{2}<50 \%\right)^{17,18}$. The Hardy-Weinberg equilibrium results were extracted from original studies or calculated using the original data. We used leave-one-out sensitivity 
analysis to judge the robustness and reliability of the results. Revman 5.3 software (Nordic Cochrane Centre, Cochrane Collaboration, Copenhagen, Sweden) was used to generate Forest and funnel plots.

\section{Functional predictions}

To explore the annotations of the human non-coding genome. Functional analyses were performed using the in silico tool HaploReg 4.1

(http://pubs.broadinstitute.org/mammals/haploreg/haploreg.php).

\section{Results}

\section{Study characteristics}

The primary search of the four databases harvested 206 records: 72 from PubMed, 80 from Embase, 11 from Cochrane library, and 43 from China National Knowledge Infrastructure (CNKI). After removed duplicated and irrelevant records. 13 articles were ultimately went into the process of meta-analysis. The detailed process of the literature search and screen is shown in Figure 2. Of the 13 articles, 11 articles containing original data for rs610604. These studies were performed in UK $^{19}$, Egypt ${ }^{20}$, India ${ }^{21}$, China $^{22-25}$, Pakistani $^{26}$, USA $^{27}$, Sweden $^{28}$, México $^{29}$. In all, These studies included 11,556 psoriasis patients and 16,720 controls. As for rs17728338, there were 9 articles involved in them, they were conducted in UK ${ }^{19}$, Europe $^{30}$, China ${ }^{22,23,31}$, India ${ }^{21}$, Pakistani ${ }^{26}$, USA $^{27}$, México $^{29}$. In all, these studies containing 11,776 psoriasis patients and 17,631 controls. The detailed characteristics of every study for rs610604 and rs17728338 are shown in Table 1 and Table 2 respectively. The methodological quality of each study evaluated using NOS for nonrandomized controlled trials is shown in Table 3.

\section{Meta-analyses results}

\section{Rs610604 polymorphism and psoriasis susceptibility}

We used random effect model to evaluate the association between rs610604 polymorphism and psoriasis vulnerability owning to a significant heterogeneity among the included studies $\left(P<0.0001, I^{2}=70 \%\right)$. The results demonstrated that rs610604 was significantly associated with psoriasis risk (G vs. T, OR =1.19, $95 \%$ Cl: 1.09-1.31, $P=0.0002 ;$ Fig. 3).

\section{Rs17728338 polymorphism and psoriasis susceptibility}

Heterogeneity was small among all the studies for $\operatorname{rs} 17728338\left(P=0.41, \mathrm{I}^{2}=4 \%\right)$. therefore, fixed-effect model was used to conduct the meta-analysis. Our results revealed a significant association between rs 17728338 polymorphism and psoriasis vulnerability (A vs. G, OR = 1.69, 95\% Cl:1.58-1.80, $P<0.00001$; Fig. 4).

\section{Sensitivity analysis and publication bias}

The significance of pooled ORs and $95 \%$ Cls was not affected when we take out one study at a time, indicating that the results were stable and robust. The funnel plots of rs610604 and rs17728338 were visually symmetrical (Figs. 5 and 6), suggesting no statistically significant publication bias. 


\section{Functional analysis}

The results of functional analysis conducted using HaploReg are shown in Figure 7.

\section{Discussion}

Although the precise mechanism of human psoriasis remains somewhat enigmatic. It is increasingly recognized that strong genetic predisposition act as intrinsic factor for psoriasis pathogenesis, and SNPs in human genome may be one of the keys to unlock insights into genetic basis for the occurrence, development and relapse of psoriasis ${ }^{32,33}$. As intrinsic factors, polymorphisms in TNFAIP3 and TNIP1 gene has garnered considerable attention over the past decade years by different research teams all over the world.

Our meta-analysis results indicated that psoriasis patients had a statistically significant higher frequency of the rs610604 $\mathrm{G}$ allele. Most individual studies were in accordance with the results analysis by synthesis. The outcome of the metaanalysis remained stable after we conducted the leave-one-out sensitivity analysis. For rs17728338, The pooled outcome illustrated that the A allele of rs 17728338 have an significantly increased risk for psoriasis. To further explore the underlying mechanisms of the interaction of TNFAIP3 and TNIP1, the HaploReg 4.1 online database was used to predict the functions of the two loci in silico. According to HaploReg, enhancer histone marks for rs610604 were found in 5 different human tissues, while enhancer histone marks for rs 17728338 were found in 9 different human tissues. Both rs610604 and rs17728338 were in linkage disequilibrium with numerous other loci using a threshold of $r^{2} \geq 0.8$. Regulatory motifs changed were found in both rs610604 and rs17728338. These in silico information may help to have a better understanding of the functions of the two loci, functional experiments are strongly need to validate these hypotheses in the future.

A20 was first characterized as a cytokine-inducible factor by a seminal study of Dixit, V. M. et al in $1990^{34}$. After that, in the year of 2004, Dixit and co-workers discovered that A20 was involved in TNF-induced NF-KB activation by playing a role of dual ubiquitin-editing enzyme ${ }^{35,36}$. Dysregulation of A20 expression was found to be associated with inflammatory and autoimmune disease such as psoriasis as well as the pathogenesis of cancer over the past few years. Jiang et al.'s study ${ }^{37}$ suggested that TNFAIP3 mRNA expression level significantly correlated with the severity and pathology of psoriasis. Other studies on systemic lupus erythematosus (SLE) and type 2 diabetes reported that some of the single nucleotide polymorphisms (SNPs) can influence expression level of the TNFAIP3 ${ }^{38,39}$. As for cancer involvement, A20 mRNA was found to be upregulated in the poorly differentiated head and neck squamous cell

carcinomas (SCCs) of the skin while no A20 mRNA is observed in normal tissues samples ${ }^{40}$. The molecular mechanism of A20 functions underlying these biological processes is generally characterized as inhibitory effect of NF-KB activation by editing the ubiquitylation status of its numerous proximal signaling proteins such as receptor-interacting protein serine/threonine kinase 1 (RIPK1), TNF Receptor Associated Factor 6 (TRAF6), Mucosa-Associated Lymphoid Tissue Lymphoma Translocation Protein 1 (MALT1), etc ${ }^{41,42}$. Apart from NF-KB signaling pathway, A20 is also been reported to be involved in the regulation of other signaling circuits including Wnt pathway, interferon regulatory factor (IRF) pathway, etc ${ }^{43,44}$. There were also studies focusing on blocking autophagy and anti-apoptotic activities by deubiquitination ${ }^{45}$. However, the exact mechanisms by which it does this remains unclear. More researches are needed to explore the mechanisms underlying them.

One of the most important A20 binding protein is TNFAIP3 Interacting Protein 1 (TNIP1), which has another alias of ABIN-1. It has been reported that TNFAIP3 and TNIP1 physically interact with each other to inhibit cell death and NF-KB signaling pathway ${ }^{46,47}$. Similar with TNFAIP3, more than 3 genome-wide association studies (GWAS) indicated that TNIP1 have been implicated in numerous inflammatory disease, including psoriasis, psoriatic arthritis, systemic lupus 
erythematosus (SLE), systemic sclerosis (SSC), rheumatoid arthritis (RA) $)^{19,27,48-50}$. It is probably that A20 collaborate with TNIP1 to be involved in the pathophysiology of these disease.

To date, this is the most comprehensive meta-analysis on the correlation between TNFAIP3 and TNIP1 polymorphisms and psoriasis vulnerability. However, several drawbacks should not be overlook. First, As far as the study number and sample size is concerned, although we have gathered all the currently available evidences, false negatives of our study still exist. Second, the genetic factor for psoriasis be composed of a synergetic effect of multiple relevant genes and loci. However, we only focused on rs610604 in TNIP1 and rs17328338 in TNFAIP3. Third, only allele model was used to analyzed the data. Other genetic models are strongly recommend to be used as long as there are enough future relevant researches. Finally, only studies published in English was included in the present study; the lack of potential relevant articles written in other language may lead to selection bias.

\section{Conclusions}

The present study suggested that $\mathrm{G}$ allele of rs610604 polymorphisms in TNFAIP3 and A allele of rs17728338 polymorphisms in TNIP1 were estimated to have an increased risk for psoriasis susceptibility by using the allele model.

\section{Declarations}

\section{Competing interests}

The authors declare that there was no conflict of interests.

\section{Funding}

None

\section{Author Contributions}

Gong, H. B produced the idea and the did the first version of this paper. Gong, H. B and Gao, S. T did the literature search respectively. Kang, X. J and Wu, X. J was involved in the revising of the manuscript and provided some important intellectual ideas in our original manuscript. $\mathrm{Pu}, \mathrm{X}$. M critically revised the final manuscript and takes the responsibility for all the data analysis.

\section{Compliance with Ethical Standards}

All analyses in the present work were based on previous published literatures and online public databases, there were no human participants included in our study. Therefore, this work does not need any ethical approval and patient consent.

\section{References}

1.Di Meglio P, Villanova F, Nestle FO. Psoriasis. Cold Spring Harb Perspect Med. 2014;4(8).

2.Weigle N, McBane S. Psoriasis. Am Fam Physician. 2013;87(9):626-633.

3.Boehncke WH, Schon MP. Psoriasis. Lancet (London, England). 2015;386(9997):983-994. 
4.Takeshita J, Grewal S, Langan SM, et al. Psoriasis and comorbid diseases: Epidemiology. J Am Acad Dermatol. 2017;76(3):377-390.

5.Parisi R, Symmons DP, Griffiths CE, Ashcroft DM. Global epidemiology of psoriasis: a systematic review of incidence and prevalence. J Invest Dermatol. 2013;133(2):377-385.

6.Perera GK, Di Meglio P, Nestle FO. Psoriasis. Annu Rev Pathol. 2012;7:385-422.

7.Boehncke WH. Etiology and Pathogenesis of Psoriasis. Rheum Dis Clin North Am. 2015;41(4):665-675.

8.Capon F. The Genetic Basis of Psoriasis. Int J Mol Sci. 2017;18(12).

9.Liang Y, Sarkar MK, Tsoi LC, Gudjonsson JE. Psoriasis: a mixed autoimmune and autoinflammatory disease. Curr Opin Immunol. 2017;49:1-8.

10.Boone DL, Turer EE, Lee EG, et al. The ubiquitin-modifying enzyme A20 is required for termination of Toll-like receptor responses. Nat Immunol. 2004;5(10):1052-1060.

11.Evans PC, Ovaa H, Hamon M, et al. Zinc-finger protein A20, a regulator of inflammation and cell survival, has deubiquitinating activity. Biochem J. 2004;378(Pt 3):727-734.

12.Caster DJ, Korte EA, Nanda SK, et al. ABIN1 dysfunction as a genetic basis for lupus nephritis. J Am Soc Nephrol. 2013;24(11):1743-1754.

13.Musone SL, Taylor KE, Lu TT, et al. Multiple polymorphisms in the TNFAIP3 region are independently associated with systemic lupus erythematosus. Nat Genet. 2008;40(9):1062-1064.

14.Vereecke L, Beyaert R, van Loo G. The ubiquitin-editing enzyme A20 (TNFAIP3) is a central regulator of immunopathology. Trends Immunol. 2009;30(8):383-391.

15.Moher D, Liberati A, Tetzlaff J, Altman DG. Preferred reporting items for systematic reviews and meta-analyses: the PRISMA statement. PLoS Med. 2009;6(7):e1000097.

16. Higgins JP, Thompson SG, Deeks JJ, Altman DG. Measuring inconsistency in meta-analyses. BMJ. 2003;327(7414):557-560.

17.DerSimonian R, Laird N. Meta-analysis in clinical trials. Control Clin Trials. 1986;7(3):177-188.

18.Mantel N, Haenszel W. Statistical aspects of the analysis of data from retrospective studies of disease. J Nat/ Cancer Inst. 1959;22(4):719-748.

19.Bowes J, Orozco G, Flynn E, et al. Confirmation of TNIP1 and IL23A as susceptibility loci for psoriatic arthritis. Ann Rheum Dis. 2011;70(9):1641-1644.

20. Haase O, Mosaad H, Eldarouti MA, et al. TNFAIP3 and IL12B gene polymorphisms associated with psoriasis vulgaris in an Egyptian cohort. J Eur Acad Dermatol Venereol. 2015;29(7):1297-1301.

21.Indhumathi S, Rajappa M, Chandrashekar L, Ananthanarayanan PH, Thappa DM, Negi VS. TNFAIP3 and TNIP1 polymorphisms confer psoriasis risk in South Indian Tamils. Br J Biomed Sci. 2015;72(4):168-173.

22.Li XL, Yu H, Wu GS. Investigating the genetic association of HCP5, SPATA2, TNIP1, TNFAIP3 and COG6 with psoriasis in Chinese population. Int $\mathrm{J}$ Immunogenet. 2014;41(6):503-507. 
23.Yang Q, Liu H, Qu L, et al. Investigation of 20 non-HLA (human leucocyte antigen) psoriasis susceptibility loci in Chinese patients with psoriatic arthritis and psoriasis vulgaris. Br J Dermatol. 2013;168(5):1060-1065.

24.Zhang Z, Ma Y, Zhang Z, et al. Identification of Two Loci Associated with Generalized Pustular Psoriasis. J Invest Dermatol. 2015;135(8):2132-2134.

25.Zhang C, Zhu KJ, Liu H, et al. The TNFAIP3 polymorphism rs610604 both associates with the risk of psoriasis vulgaris and affects the clinical severity. Clin Exp Dermatol. 2015;40(4):426-430.

26.Munir S, ber Rahman S, Rehman S, et al. Association analysis of GWAS and candidate gene loci in a Pakistani population with psoriasis. Mol Immunol. 2015;64(1):190-194.

27.Nair RP, Duffin KC, Helms C, et al. Genome-wide scan reveals association of psoriasis with IL-23 and NF-kappaB pathways. Nat Genet. 2009;41(2):199-204.

28.Nikamo P, Lysell J, Stahle M. Association with Genetic Variants in the IL-23 and NF-kappaB Pathways Discriminates between Mild and Severe Psoriasis Skin Disease. J Invest Dermatol. 2015;135(8):1969-1976.

29.Villarreal-Martinez A, Gallardo-Blanco H, Cerda-Flores R, et al. Candidate gene polymorphisms and risk of psoriasis: A pilot study. Exp Ther Med. 2016;11(4):1217-1222.

30.Das S, Stuart PE, Ding J, et al. Fine mapping of eight psoriasis susceptibility loci. Eur J Hum Genet. 2015;23(6):844853.

31.Han JW, Wang Y, Alateng C, et al. Tumor Necrosis Factor-alpha Induced Protein 3 Interacting Protein 1 Gene Polymorphisms and Pustular Psoriasis in Chinese Han Population. Chin Med J (Engl). 2016;129(13):1519-1524.

32.Ray-Jones H, Eyre S, Barton A, Warren RB. One SNP at a Time: Moving beyond GWAS in Psoriasis. J Invest Dermatol. 2016;136(3):567-573.

33.Linares-Pineda TM, Canadas-Garre M, Sanchez-Pozo A, Calleja-Hernandez MA. Gene polymorphisms as predictors of response to biological therapies in psoriasis patients. Pharmacol Res. 2016;113(Pt A):71-80.

34.Dixit VM, Green S, Sarma V, et al. Tumor necrosis factor-alpha induction of novel gene products in human endothelial cells including a macrophage-specific chemotaxin. J Biol Chem. 1990;265(5):2973-2978.

35.Wertz IE, O'Rourke KM, Zhou H, et al. De-ubiquitination and ubiquitin ligase domains of A20 downregulate NF-kappaB signalling. Nature. 2004;430(7000):694-699.

36.Opipari AW, Jr., Hu HM, Yabkowitz R, Dixit VM. The A20 zinc finger protein protects cells from tumor necrosis factor cytotoxicity. J Biol Chem. 1992;267(18):12424-12427.

37.Jiang X, Tian H, Fan Y, et al. Expression of tumor necrosis factor alpha-induced protein 3 mRNA in peripheral blood mononuclear cells negatively correlates with disease severity in psoriasis vulgaris. Clin Vaccine Immunol.

2012;19(12):1938-1942.

38.Adrianto I, Wen F, Templeton A, et al. Association of a functional variant downstream of TNFAIP3 with systemic lupus erythematosus. Nat Genet. 2011;43(3):253-258.

39.Boonyasrisawat W, Eberle D, Bacci S, et al. Tag polymorphisms at the A20 (TNFAIP3) locus are associated with lower gene expression and increased risk of coronary artery disease in type 2 diabetes. Diabetes. 2007;56(2):499-505. 
40.Codd JD, Salisbury JR, Packham G, Nicholson LJ. A20 RNA expression is associated with undifferentiated nasopharyngeal carcinoma and poorly differentiated head and neck squamous cell carcinoma. $J$ Pathol. 1999;187(5):549-555.

41.Hymowitz SG, Wertz IE. A20: from ubiquitin editing to tumour suppression. Nat Rev Cancer. 2010;10(5):332-341.

42.Vereecke L, Beyaert R, van Loo G. Genetic relationships between A20/TNFAIP3, chronic inflammation and autoimmune disease. Biochem Soc Trans. 2011;39(4):1086-1091.

43.Shao L, Oshima S, Duong B, et al. A20 restricts wnt signaling in intestinal epithelial cells and suppresses colon carcinogenesis. PLoS One. 2013;8(5):e62223.

44.Saitoh T, Yamamoto M, Miyagishi M, et al. A20 is a negative regulator of IFN regulatory factor 3 signaling. $\mathrm{J}$ Immunol. 2005;174(3):1507-1512.

45.Catrysse L, Vereecke L, Beyaert R, van Loo G. A20 in inflammation and autoimmunity. Trends Immunol. 2014;35(1):22-31.

46.Parvatiyar K, Harhaj EW. Regulation of inflammatory and antiviral signaling by A20. Microbes Infect. 2011;13(3):209215.

47. Mauro C, Pacifico F, Lavorgna A, et al. ABIN-1 binds to NEMO/IKKgamma and co-operates with A20 in inhibiting NFkappaB. J Biol Chem. 2006;281(27):18482-18488.

48.Kawasaki A, Ito S, Furukawa $\mathrm{H}$, et al. Association of TNFAIP3 interacting protein 1, TNIP1 with systemic lupus erythematosus in a Japanese population: a case-control association study. Arthritis Res Ther. 2010;12(5):R174.

49.Allanore $Y$, Saad M, Dieude P, et al. Genome-wide scan identifies TNIP1, PSORS1C1, and RHOB as novel risk loci for systemic sclerosis. PLoS Genet. 2011;7(7):e1002091.

50.Gallagher J, Howlin J, McCarthy C, et al. Identification of Naf1/ABIN-1 among TNF-alpha-induced expressed genes in human synoviocytes using oligonucleotide microarrays. FEBS Lett. 2003;551(1-3):8-12.

\section{Abbreviations}

SNP

Single nucleotide polymorphism

CNKI

China National Knowledge Infrastructure

NOS

Newcastle-Ottawa scale

TNFAIP3

Tumor Necrosis Factor Alpha-Induced Protein 3

TNIP1 
TNFAIP3 Interacting Protein 1

OR

Odds ratio

$\mathrm{Cl}$

Confidence interval

HWE

hardy-weinberg equilibrium

GWAS

Genome-wide association study

RIPK1

Receptor-interacting protein serine/threonine kinase 1

TRAF6

TNF Receptor Associated Factor 6

MALT1

Mucosa-Associated Lymphoid Tissue Lymphoma Translocation Protein 1

IRF

Interferon regulatory factor

SLE

Systemic lupus erythematosus

SSC

Systemic sclerosis

RA

Rheumatoid arthritis

\section{Tables}

Table 1. Main characteristics of included studies 


\begin{tabular}{|c|c|c|c|c|c|c|c|c|c|}
\hline \multirow[t]{2}{*}{ Study } & \multirow[t]{2}{*}{ Year } & \multirow[t]{2}{*}{ Country } & \multirow[t]{2}{*}{ Ethnicity } & \multirow[t]{2}{*}{ Case/Control } & \multicolumn{2}{|c|}{ Case } & \multicolumn{2}{|c|}{ Control } & \multirow[t]{2}{*}{ HWE } \\
\hline & & & & & $\bar{M}$ & $\overline{\mathrm{W}}$ & $\mathrm{M}$ & $\mathrm{W}$ & \\
\hline Rs610604 (T/G) & & & & & & & & & \\
\hline Bowes $(1)^{19}$ & 2011 & UK & UK & $742 / 5198$ & 520 & 844 & 3286 & 7110 & 0.04 \\
\hline Bowes (2) 19 & 2011 & UK & Ireland & $161 / 334$ & 102 & 220 & 235 & 433 & 1 \\
\hline Haase $^{20}$ & 2014 & Egypt & Egyptian & $132 / 175$ & 123 & 141 & 118 & 232 & 0.016 \\
\hline Indhumathi $^{21}$ & 2015 & India & Indian & $360 / 360$ & 260 & 460 & 202 & 518 & 0.223 \\
\hline $\mathrm{Li}^{22}$ & 2014 & China & Chinese & $201 / 300$ & 20 & 382 & 58 & 542 & 0.754 \\
\hline Munir 26 & 2015 & Pakistani & Asian & $533 / 373$ & 354 & 712 & 320 & 746 & $>0.05$ \\
\hline Nair $(1)^{27}$ & 2009 & USA & Caucasian & $1359 / 1400$ & 1017 & 1701 & 890 & 1510 & NA \\
\hline Nair (2) 27 & 2009 & USA & Caucasian & $5048 / 5051$ & 3635 & 6461 & 3233 & 6869 & NA \\
\hline Nikamo $^{28}$ & 2015 & Sweden & Caucasian & $1411 / 1529$ & 1040 & 1782 & 979 & 2079 & NA \\
\hline Villarreal-Martínez ${ }^{29}$ & 2016 & México & México & $46 / 103$ & 38 & 54 & 91 & 115 & 1 \\
\hline Yang 23 & 2012 & China & Chinese & $974 / 1181$ & 187 & 1761 & 189 & 2173 & 0.05 \\
\hline Zhang, Z ${ }^{24}$ & 2015 & China & Chinese & $238 / 420$ & 62 & 414 & 84 & 756 & 0.914 \\
\hline Zhang, $C^{25}$ & 2015 & China & Chinese & $351 / 296$ & 105 & 597 & 61 & 531 & 0.928 \\
\hline
\end{tabular}

M, mutant allele; W, wild allele; HWE, Hardy-Weinberg Equilibrium

Table 2. Main characteristics of included studies

\begin{tabular}{|c|c|c|c|c|c|c|c|c|c|}
\hline \multirow[t]{2}{*}{ Study } & \multirow[t]{2}{*}{ Year } & \multirow[t]{2}{*}{ Country } & \multirow[t]{2}{*}{ Ethnicity } & \multirow[t]{2}{*}{ Case/Control } & \multicolumn{2}{|c|}{ Case } & \multicolumn{2}{|c|}{ Control } & \multirow[t]{2}{*}{ HWE } \\
\hline & & & & & $\mathrm{M}$ & $\mathrm{W}$ & $\bar{M}$ & $\mathrm{~W}$ & \\
\hline \multicolumn{10}{|l|}{ Rs17728338 (G/A) } \\
\hline Bowes $(1)^{19}$ & 2011 & UK & UK & $742 / 5198$ & 114 & 1370 & 572 & 9824 & 0.42 \\
\hline Bowes $(2)^{19}$ & 2011 & UK & Ireland & $161 / 334$ & 29 & 293 & 33 & 635 & 0.04 \\
\hline Das $^{30}$ & 2015 & Europe & European & $2212 / 2855$ & 398 & 4026 & 286 & 5424 & NA \\
\hline $\mathrm{Han}^{31}$ & 2016 & China & Han population & $140 / 476$ & 54 & 226 & 85 & 867 & $>0.05$ \\
\hline Indhumathi $^{21}$ & 2015 & India & Indian & $360 / 360$ & 202 & 518 & 147 & 573 & 0.747 \\
\hline $\mathrm{Li}^{22}$ & 2014 & China & Chinese & $201 / 300$ & 56 & 544 & 40 & 560 & 0.754 \\
\hline Munir $^{26}$ & 2015 & Pakistani & Asian & $533 / 373$ & 142 & 924 & 67 & 679 & $>0,05$ \\
\hline Nair $(1)^{27}$ & 2009 & USA & Caucasian & $1359 / 1400$ & 253 & 2465 & 157 & 2643 & NA \\
\hline Nair $(2)^{27}$ & 2009 & USA & Caucasian & $5048 / 5051$ & 878 & 9218 & 546 & 9556 & NA \\
\hline Villarreal-Martínez ${ }^{29}$ & 2016 & México & México & $46 / 103$ & 11 & 81 & 11 & 195 & 0.245 \\
\hline Yang 23 & 2012 & China & Chinese & $974 / 1181$ & 276 & 1672 & 213 & 2149 & 1 \\
\hline
\end{tabular}

M, mutant allele; W, wild allele; HWE, Hardy-Weinberg Equilibrium;

Table 3. Quality assessment of included studies according to the Newcastle-Ottawa Scale 


\begin{tabular}{|c|c|c|c|c|c|c|c|c|c|}
\hline$\overline{\mathrm{n} / \text { Study }}$ & $\begin{array}{c}\text { Adequate } \\
\text { definition } \\
\text { of cases }\end{array}$ & $\begin{array}{c}\text { Representativeness } \\
\text { of cases }\end{array}$ & $\begin{array}{l}\text { Selection } \\
\text { of } \\
\text { control } \\
\text { subjects }\end{array}$ & $\begin{array}{l}\text { Definition } \\
\text { of control } \\
\text { subjects }\end{array}$ & $\begin{array}{l}\text { Control } \\
\text { for } \\
\text { important } \\
\text { factor or } \\
\text { additional } \\
\text { factor }\end{array}$ & $\begin{array}{c}\text { Exposure } \\
\text { assessment }\end{array}$ & $\begin{array}{c}\text { Same method } \\
\text { of } \\
\text { ascertainment } \\
\text { for all } \\
\text { subjects }\end{array}$ & $\begin{array}{l}\text { Non- } \\
\text { response } \\
\text { rate }\end{array}$ & $\begin{array}{l}\text { Total } \\
\text { score }\end{array}$ \\
\hline $\begin{array}{l}\mathrm{Nes}^{19} \\
.1\end{array}$ & 1 & 0 & 1 & 1 & 1 & 1 & 1 & 1 & 7 \\
\hline$j^{30} 2015$ & 1 & 0 & 1 & 1 & 1 & 1 & 1 & 1 & 7 \\
\hline $\begin{array}{l}\mathrm{ase}^{20} \\
.4\end{array}$ & 1 & 0 & 1 & 1 & 1 & 1 & 1 & 1 & 7 \\
\hline $\mathrm{n}^{31} 2016$ & 1 & 0 & 1 & 1 & 1 & 1 & 1 & 1 & 7 \\
\hline $\begin{array}{l}\text { humathi } \\
.5\end{array}$ & 1 & 0 & 1 & 1 & 1 & 1 & 1 & 1 & 7 \\
\hline${ }^{2} 2014$ & 1 & 0 & 0 & 1 & 1 & 1 & 1 & 1 & 6 \\
\hline $\begin{array}{l}\operatorname{nir}^{26} \\
.5\end{array}$ & 1 & 0 & 1 & 1 & 1 & 1 & 1 & 1 & 7 \\
\hline$i^{27} 2009$ & 1 & 0 & 1 & 1 & 1 & 1 & 1 & 1 & 7 \\
\hline $\begin{array}{l}\mathrm{amo}^{28} \\
.5\end{array}$ & 1 & 0 & 0 & 1 & 1 & 1 & 1 & 1 & 6 \\
\hline $\begin{array}{l}\text { arreal- } \\
\text { rtínez } \\
.6\end{array}$ & 1 & 0 & 1 & 1 & 1 & 1 & 1 & 1 & 7 \\
\hline $\lg ^{23} 2011$ & 1 & 0 & 1 & 1 & 1 & 1 & 1 & 1 & 7 \\
\hline $\begin{array}{l}\text { ing, } Z^{24} \\
.5\end{array}$ & 1 & 0 & 1 & 1 & 1 & 1 & 1 & 1 & 7 \\
\hline $\begin{array}{l}\text { ing, } C^{25} \\
.5\end{array}$ & 1 & 0 & 0 & 1 & 1 & 1 & 1 & 1 & 6 \\
\hline
\end{tabular}

\section{Figures}

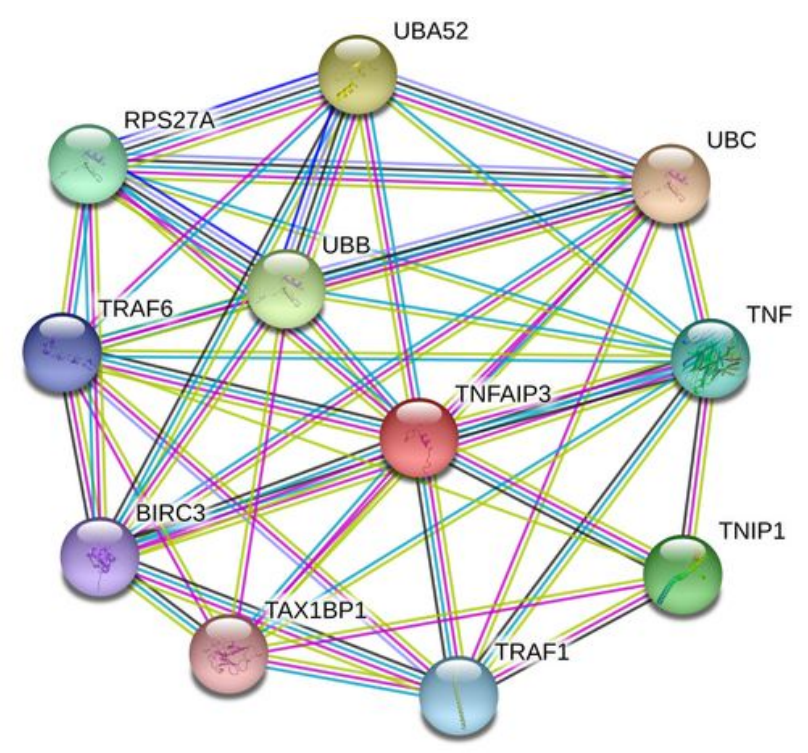

Figure 1

Network of TNFAIP3, TNIP1 and their closest functional partners. These data were from the Search Tool for the Retrieval of Interacting Genes (STRING) database (http://string-db.org/) 


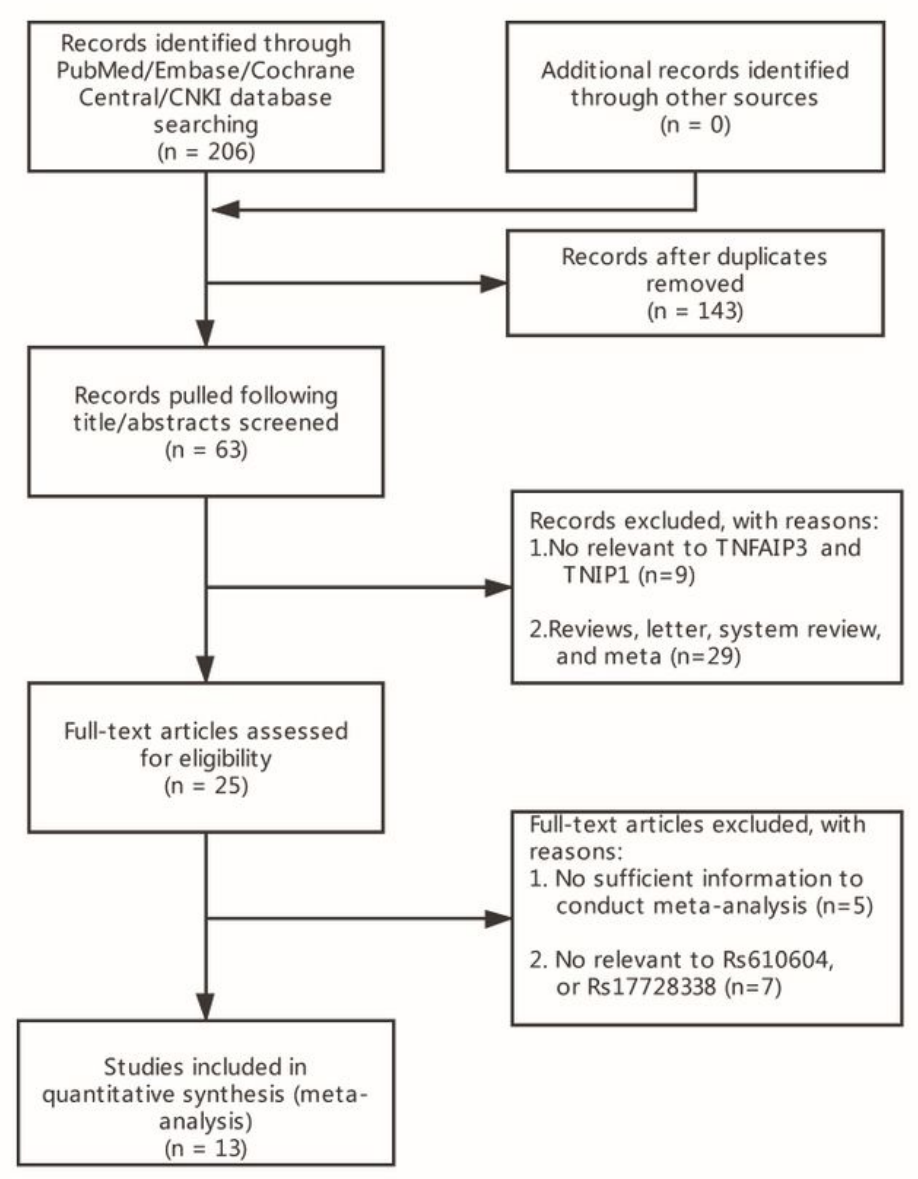

Figure 2

Flow diagram of literature search and screen 


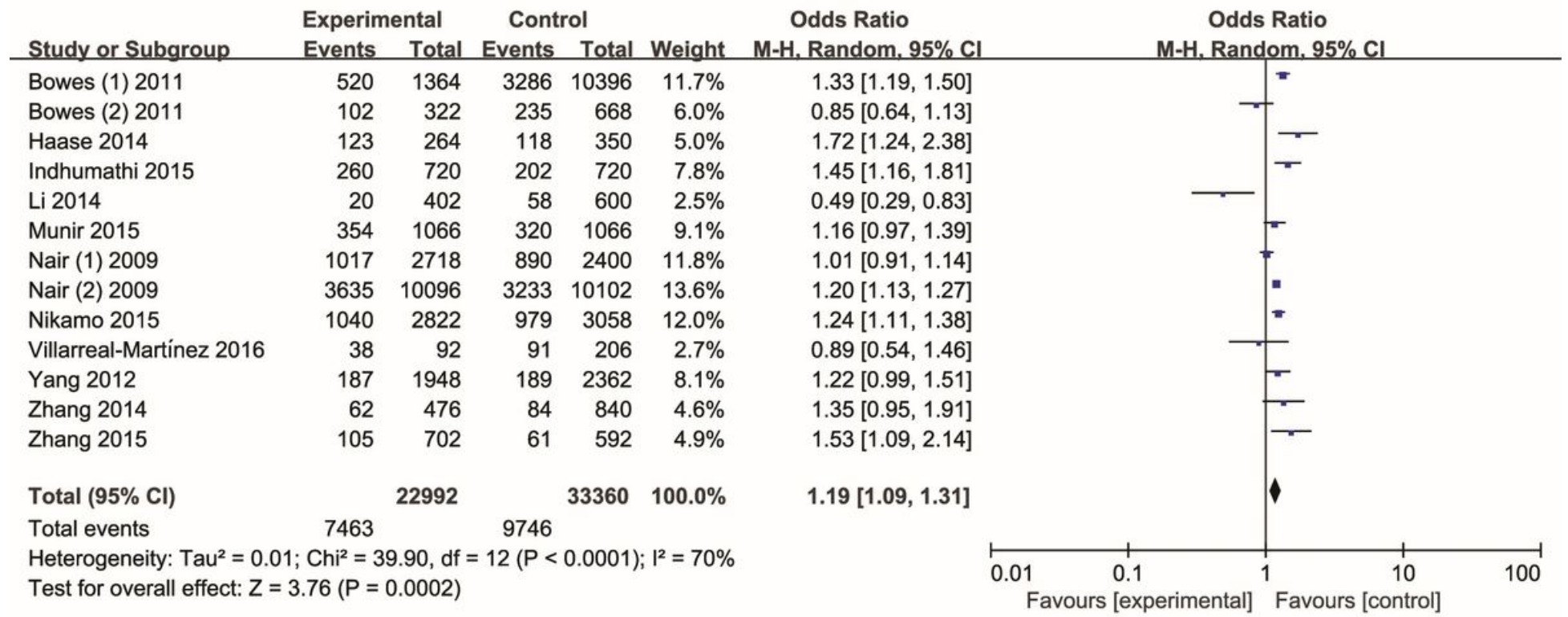

\section{Figure 3}

Forest plot of rs610604 in TNFAIP3 gene and risk of psoriasis

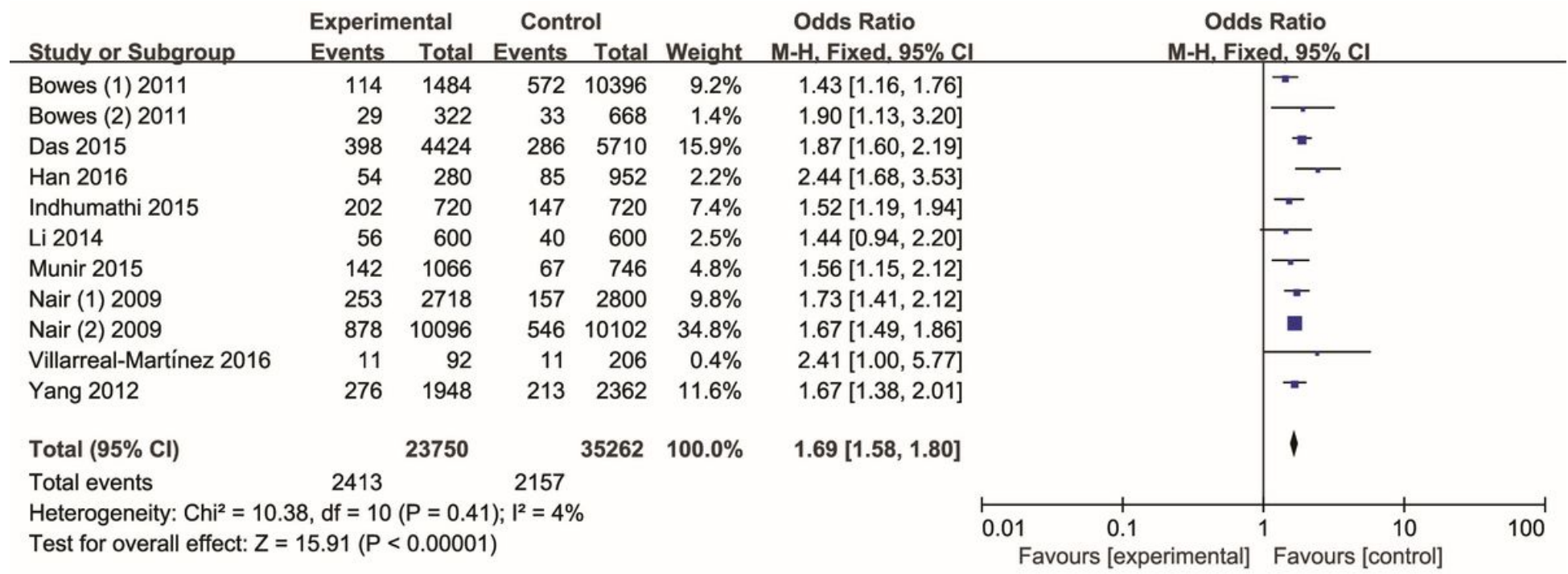

\section{Figure 4}

Forest plot of rs17728338 in TNIP1 gene and risk of psoriasis 


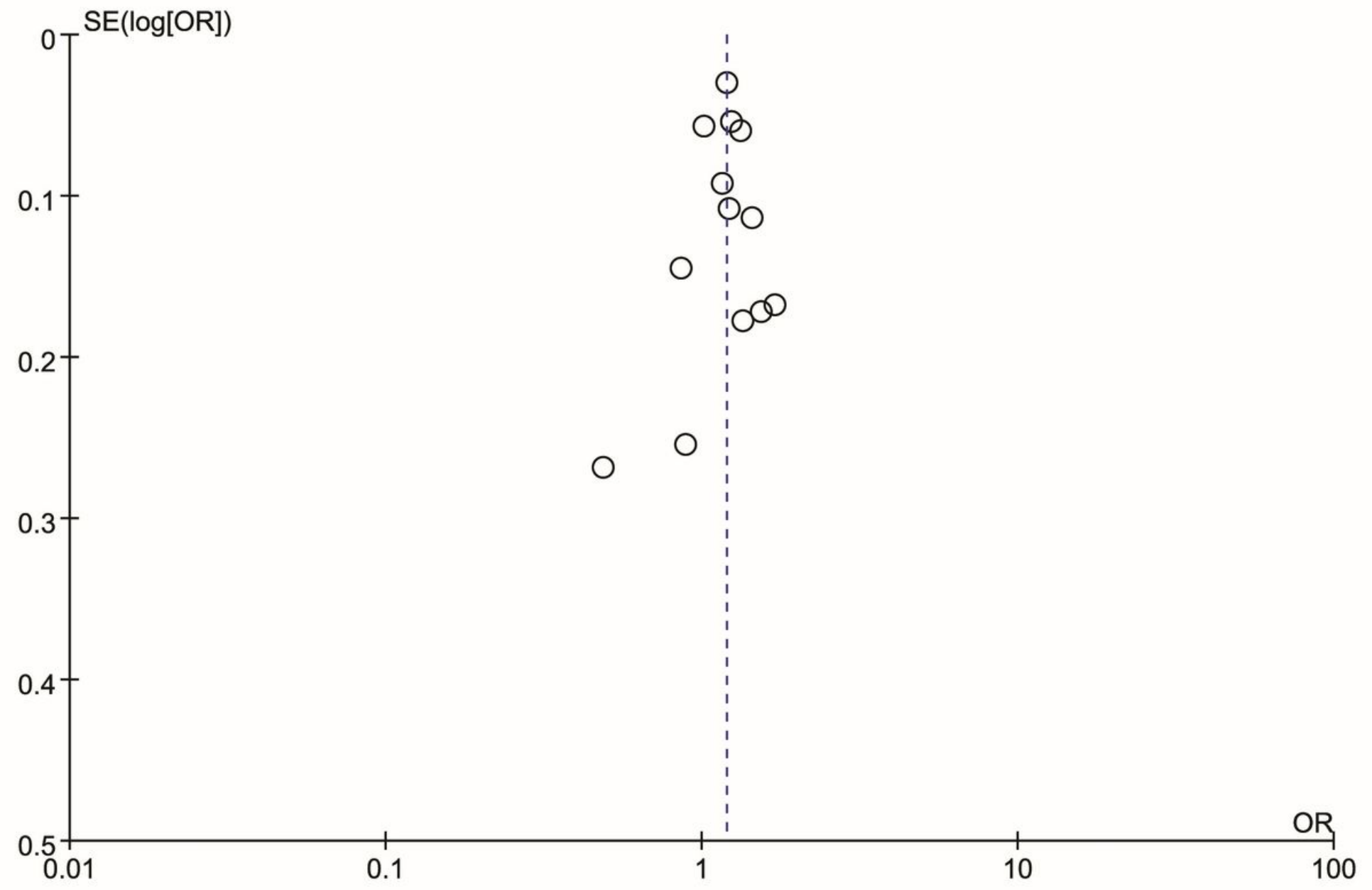

Figure 5

Funnel plot of rs610604 in TNFAIP3 gene and risk of psoriasis 


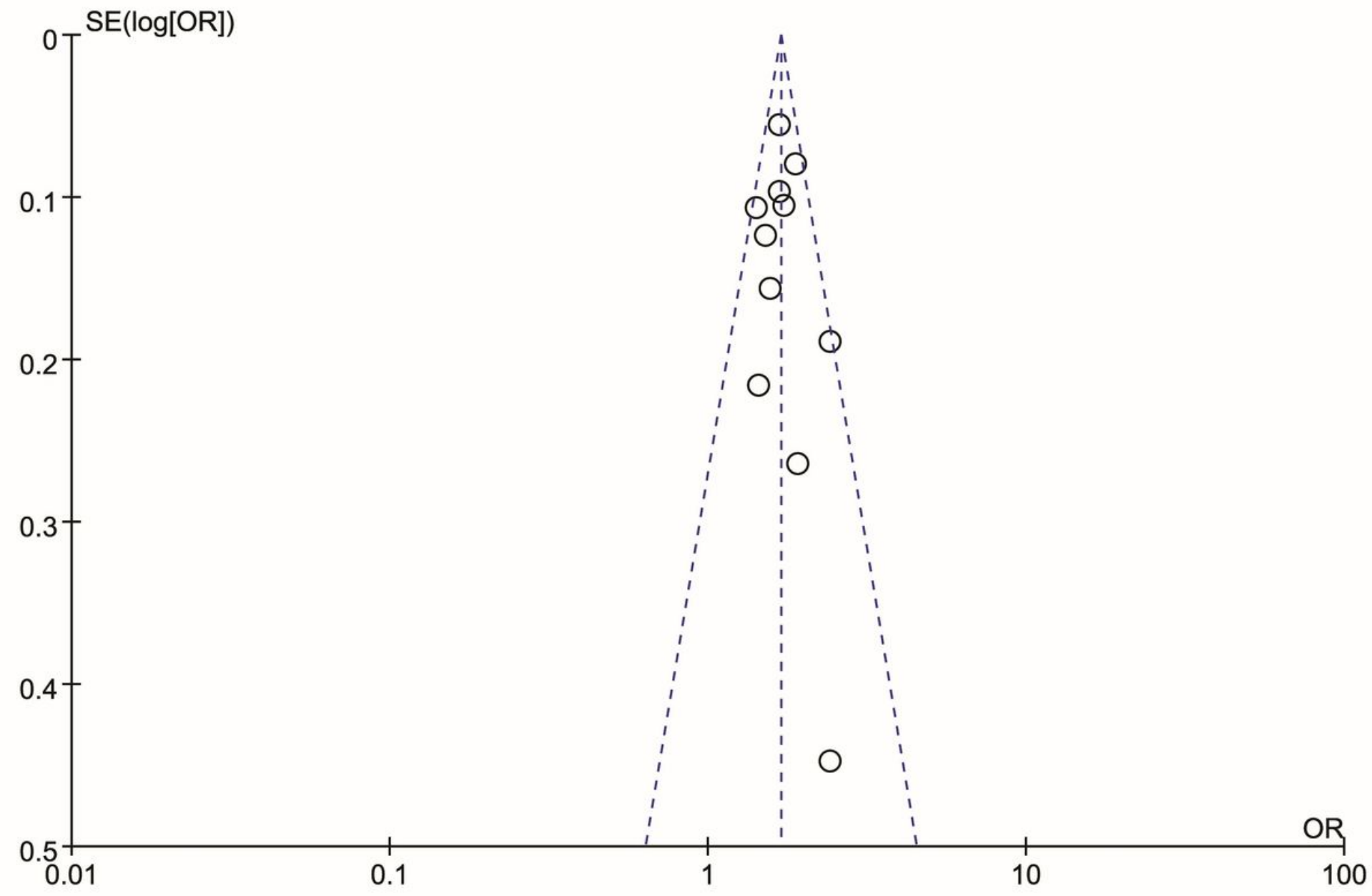

Figure 6

Funnel plot of rs17728338 in TNIP1 gene and risk of psoriasis 


\section{A}

Query SNP: rs610604 and variants with $\mathrm{r}^{2}>=0.8$

\begin{tabular}{|c|c|c|c|c|c|c|c|c|c|c|c|c|c|c|c|c|}
\hline chr & $r_{\text {(hg38) }}^{\text {pos }}$ & $\begin{array}{l}\text { LD } \\
\left(r^{2}\right)\end{array}$ & $\begin{array}{l}\text { LD } \\
\left(D^{\prime}\right)\end{array}$ & variant & Ref & $\begin{array}{l}\text { Alt AFR AMR } \\
\text { freq freq }\end{array}$ & $\begin{array}{l}\text { R ASN EUR SiPhy } \\
\text { freq freq cons }\end{array}$ & $\begin{array}{l}\text { Promoter } \\
\text { histone } \\
\text { marks }\end{array}$ & $\begin{array}{l}\text { Enhancer } \\
\text { histone marks }\end{array}$ & DNAse & $\begin{array}{l}\text { Proteins } \\
\text { bound }\end{array}$ & $\begin{array}{l}\text { s Motifs } \\
\text { changed }\end{array}$ & $\begin{array}{l}\text { NHGRI/EBI GRASP } \\
\text { GWAS hits } \mathrm{QTL} \\
\text { hits }\end{array}$ & $\begin{array}{l}\text { Selected } \\
\text { eQTL } \\
\text { hits }\end{array}$ & $\begin{array}{l}\text { GENCODE } \\
\text { genes }\end{array}$ & $\begin{array}{l}\text { dbSNNP } \\
\text { func } \\
\text { annot }\end{array}$ \\
\hline 6 & 137873904 & 40.9 & 1 & rs629953 & A & $G \quad 0.110 .55$ & 0.830 .65 & 5 tissues & 15 tissues & BLD, LNG & & 5 altered motifs & & & TNFAIP3 & intronic \\
\hline 6 & 137874824 & 40.861 & & rs 71670547 & 7 TCTC & $C T \quad 0.110 .55$ & 0.830 .64 & & 15 tissues & 8 tissues & & 5 altered motifs & & & TNFAIP3 & intronic \\
\hline 6 & 137876194 & 40.91 & 1 & rs 661561 & A & C 0.110 .55 & 0.830 .65 & & BLD, THYM & BLD & & Mef2 & & & TNFAIP3 & intronic \\
\hline 6 & 137878280 & & 1 & rs 510604 & G & T $\quad 0.300 .59$ & 0.910 .67 & & 5 tissues & 15 tissues & PU1 & TBX5 & 2 hits & & TNFAIP3 & intronic \\
\hline & 1272950 & & $=\cap 00$ & כona1 & $r$ & $T \cap 32 \cap a 2$ & nan $\cap a 7$ & & & & & & & & $2.6 \mathrm{~kb} \mathrm{3} 3^{\prime}$ of & \\
\hline
\end{tabular}

\section{Figure 7}

Haploreg view of rs610604 and rs17728338 in IL-23R gene using HaploReg version 4.1. (A) rs610604; (B) rs17728338. 